\title{
Impact of Financial Antecedents on Financial Performance of SMEs
}

\author{
Yadavalli Srinivasarao $^{1}$, Dr. N. Giri Babu ${ }^{2}$, Dr. T. Narayana Reddy ${ }^{3}$ \\ ${ }^{1}$ Research Scholar, Department of Management Studies, JNTU Anantapur, Andhra Pradesh, India \\ ${ }^{2}$ Associate professor, Dept. Of Management Studies, SVCET, Chittoor, Andhra Pradesh, India \\ ${ }^{3}$ Assistant professor, Dept. Of Management Studies, JNTU Anantapur, Andhra Pradesh, India
}

Corresponding Author: Yadavalli Srinivasarao

\begin{abstract}
Small and medium-sized companies (SMEs) have an essential role in every economy, being prepared to build jobs, support the progress of the Gross Domestic Product ( GDP), leave improvement and improve other economic exercises. The research explores the impact of various financial variables on the financial results of SMEs. The study is based on an investigative technique using a sample of selected small and medium-sized enterprises in Chittoor, AP. 66 SMEs were taken as a sample. This paper was used to test hypothetical relationships using the non-parametric Pearson chi-square test and Pearson's correlation method. The aftereffects of the non-parametric test demonstrate the statistical consequences for financial variables and the efficiency of SMEs. The test strongly stipulates that financial management rehearsals, policymakers, accomplices for improving, SME owners and managers may use these results in Andhra Pradesh to develop their business.
\end{abstract}

KEYWORDS: Financial Factors, Financial Performance, SMEs, Economy, and GDP

\section{INTRODUCTION}

Small and medium-sized undertakings are the Indian business' greatest organ. SMEs make huge commitments to any country's economic and social development regardless of its growth. The novel component of Small and Medium Enterprises (SMEs) is less capital endeavour and high maintenance of labour that has made this segment exceptionally imperative. The idea of the organizations in this part assumes an imperative part to reduce destitution and push supportable development and impartial dispersion of revenue in India. SMEs play a key role in proficiently distributing the massive labour supply and finite resources by upgrading the manufacturing process with an increase in labour. SMEs generate private ownership, promote entrepreneurship and adaptability to respond rapidly to varying consumer demands and supply environments. According to the Commissioner of Development for Micro, Small and Medium Enterprises (2001), this area would provide the nation with great job opportunities following the agricultural sector.

The word SMEs conceals a wide variety of findings and measures and exposes SMEs' perspectives from one nation to the next. A quota of the ordinarily used frameworks is the number of workers, gross net assets, revenue and level of investment. In India as per capital of the organization SMEs category done. Which business organizations have capital among 25 lakhs to 5 crores were come under Small Enterprises and which has capital amid 5 crores to 10 crores (Development Commissioner of MSME, 2009).

\subsection{Contribution of SMEs}

The reach of individual SMEs is small; however, they have grown overall in the national economies as overwhelming players. Because of the largest number of units and their openings, the phenomenal prominence of small and medium businesses in India is. This part assumes a notable fragment of the development and work of minorities, backwards-class citizens and women. The industry is assessed to employ some 59 million people in over 26 million units across the world. More than 6000 items go from customary to creative goods produced by micro, small and medium-sized companies in India. The advantages of SMEs have given the Five-Year Plans from their beginnings a special status and value. The MSME component recently had a predictable higher rate of development compared to the main mechanical field. In this globalisation situation, the Indian Administration has felt that the global strength of the MSMEs should be enhanced by rearranging systems and processes, by tranquil access to capital and by increasing their effectiveness in the global appreciation chain. In order to encourage and improve MSMEs, the legislature has introduced several plans/projects to comply with the part's criteria (Rai, 2009). An annual report by the Ministry of MSME (2010-11) shows that, in terms of esteem, it is about 45 per cent of industrial production and 40 per cent of the country's overall exports.

\subsection{Financial Management}

Financial Management alludes to the expert and viable management of money (funds) in such how on the win the targets of the entity. It's the precise capability specifically 


\section{"Impact of Financial Antecedents on Financial Performance of SMEs"}

connected with the highest management. The spatial relation of this performance is not found within the 'Line' nevertheless in addition within the boundary of 'Staff' in by an enormous of a company. It's been considered contrastingly by varied experts within the arena.

The word usually applies to the money-related policy of a business or corporation, whereas a fund or financial life management refers to an individual's management approach. It includes how to collect money, i.e. capital planning, and how to allow capital. For long-term planning as well as how transitional assets like current liabilities can be dispensed. It also handles investors' benefit plans.

\section{REVIEW OF LITERATURE}

2.1 Financial management applies and business performance of SMEs

Abanis Turyahebwa et al. (2013) the connection between financial performances practices and small and medium-sized venture performance. It was obvious from their perceptions that a solid direct relationship existed between financial performance practices and SMEs ' business performance. What's more, the outcome likewise demonstrates plainly that there has been an outright and essential connection between the maintenance of working capital and the performance of SMEs.

Babar Zaheer Butt et al. (2010) examined that association between organizational performance and financial management applies. The study was concluded that financial practices directly effect on the firm's performance. More than that the financial manager's awareness of working capital management, capital structure decisions very important other than dividend policy and investment appraisal for the performance of SMEs.

Dr Belal Youself AL Smirat (2016) broke down the effect on the financial performance of SMEs of cash management practices. The researcher found that numerous proprietors of SMEs don't have sophisticated cash management practice knowledge. The examination demonstrated that cash management is strongly affecting SME performance. Among the financial performance of SMEs and successful cash management practices, there was a considerable positive relationship.

Hande Karadag (2015) SMEs are confronting major financial difficulties studied. SMEs are confronting major financial related difficulties contemplated. The researcher noticed that the primary driver of SME failure is the absence of proper financial planning, constrained access to funding, spontaneous development, and low financial projection, and inordinate fixed assets management, lack of capital and blunder of capital. Researchers additionally noticed that sound cash management practices are critical to the survival of SMEs

Hendrik Wolmarans and Quentin Meintjes (2015) the job of financial management rehearses in the achievement of SMEs has been assessed. The study uncovered that the administration of working capital emphatically impacts the gainfulness of SMEs just as the effect of cash flow rehearses on SMEs ' performance. According to the investigation, short - term management issues majorly affect the performance of small and medium - measured undertakings than medium and long - term

Irena Jindrichovska (2013) reviewed many studies to analyze the perilous concerns of small and medium enterprises. The result revealed that an organization would never see long terms if it could not plan a proper strategy to handle its working capital effectively. The study evident that Poor owner-manager financial administration is the primary driver behind the issues looked by SMEs.

Kamilah Ahmad (2017) analysed the usage of the management bookkeeping rehearses in small and mediumsized endeavours and the connection among MAPs and SME performance. The investigation discoveries uncover that a few MAPs have huge performance connections and these discoveries have reinforced the significance of MAPs in today's organization.

Kilonzo Jennifer M, Ouma Dennis (2015) in their research paper aimed to persuade proportions of financial management practices engaged by the SMEs and their impact on growth. As per their results sound financial practices leads to better performance of SMEs. Availability of the working capital greatly influences the performance of SMEs.

Mohd Azian Husin and Mohamed Dahlan Ibrahim (2014) evaluated the part of accounting amenities and the effect on SMEs performance. The results of the study resolved that SMEs performance strongly influenced by various accounting services.

P. S. Vohra \& J. S. Dhillon (2014) in their study they were identified the great requirement of financial management practices and strategies to achieving better financial performance. As per their experiments, they concluded that financial forecasting and budgetary planning capability greatly impact on the financial performance of SMEs. And also they evident that working capital availability, financial reporting analysis potentialities vitally contributed towards the performance of SMEs.

Saqib Muneer et al. (2017) scrutinised the upshot of financial management practices on the productivity of SMEs. The observation open that most of the SMEs having accountants for managing accounts department. Firms are very familiar with cash budgeting. Firms are regularly and frequently preparing balance sheets and income and expenditure statements. The data analysis evident that there was a crucial influence of financial management practices on SMEs profitability.

Tim Mazzarol et al. (2015) were analyzed that financial management hones in small and medium enterprises (SMEs) from an investigation of 289 SMEs proprietor and supervisors in different areas of Australia and Singapore. According to their study major, SMEs are informal and their financial practices are based on the objectives may change. Most of the 
firms would like to invest their own funds rather than procuring from outside.

U. A. H. A. Rathnasiri (2015) in her research paper investigated the variances in espousal of financial management utensils and techniques in SMEs grounded on various elements of Srilanka SMEs. This study was revealed that Srilanka SMEs were operating their business based on borrowing capital rather than equity capital. By this reason the profitability of these SMEs was low.

\section{RESEARCH METHODOLOGY}

\subsection{Research question}

Is the performance of small and medium-sized enterprises influenced by financial management practices?

\subsection{Objectives of the study}

- To ascertain the key antecedents influencing SMEs financial performance

- To suggest the best financial practices that help to improve the progress of SMEs

\subsection{Hypotheses}

H1 Financial reporting \& analysis influence the performance of SMEs

$\mathbf{H}_{2}$ Fixed assets management influence the performance of SMEs

$\mathbf{H}_{3}$ Capital structure management influence the performance of SMEs

$\mathbf{H}_{4}$ Working capital management influence the performance of SMEs

\subsection{Data source and sample}

This research study is intended to describe the financial management practices of SMEs to investigate their influence on the financial performance of SMEs. Subsequently, descriptive research has opted for this research. The survey method is utilized in this exploration to examine and depict SMEs 'financial management practices. The questionnaire was structured and delivered straightforwardly to small and medium-sized undertakings to gather information on financial management rehearses and here all things were measured on the 5-point scale of Likert. The study used modest random sampling technique for selecting the sample size. Every individual from the populace has known the chance of being incorporated in the sampling using probabilistic sampling. The investigation chose an example of 66 SMEs in Chittoor District out of an aggregate of 207 SMEs.

\subsection{Methodology}

The approach used to accomplish these goals reflects a conceptual structure and describes the independent and dependent variables and their operationalization.

Speculated relationship among variables in the research The following figure illustrates that financial factors such as Financial Reporting Analysis, Fixed (Non-current) Assets Management, Capital Structure Management, and Working Capital Management will directly affect the performance of SMEs.

\section{Graph 3.1: Theoretical Framework}

Financial Reporting Analysis (FRA)
Management (FAM)
Capital Structure Management
(CSM)

Theoretical Framework developed by the researcher

\section{Techniques for data analysis}

The consistency review of the data was carried out to boost the accuracy of the evaluation. Cronbach's alpha coefficient evaluated the internal uniformity of different financial accounting activities.

Results show that the Cronbach alpha coefficient exceeds the generally agreed 0.7 criteria for each financial accounting practice. The data obtained from various SMEs' financial management activities are considered reliable data.

\section{RESULTS AND DISCUSSION}

Outcomes indicate that SMEs' financial management activities are characterized based on four variables observed, the financial reporting system, fixed management of assets, decisions on capital structures, and management of working capital.

\subsection{Financial Reporting and Analysis on Financial Performance of SMEs}

The study reveals that $88 \%$ of the SMEs are following Indian accounting standards while preparing their financial reports. 
Majority SMEs (79\%) follow the GAAP norms for preparing financial reports. But $37 \%$ of SMEs do not publish their annual reports.

\subsection{Fixed Asset Management on Financial Performance of SMEs}

The study establishes that preponderant (66\%) SMEs are not labelled to their fixed properties. Every fixed asset decision (95\%) should be taken by the top management of the organization. Regularly SMEs are calculating fixed property values $(86 \%)$.

\subsection{Capital Structure Management on Financial Performance of SMEs}

The study identified that all most all SMEs are preserving cheaper capital structures. Every SME fully utilizing its debt facility (96\%). Only $12 \%$ SMEs are dependent on own funds.

\subsection{Working Capital Management on Financial Performance of SMEs}

The study finds that all SMEs are giving high priority for their working capital management. Inventory management (98\%) is efficiently handled by SMEs. Every SME is well planned for the handling of their payments (98\%). Liquid cash (94\%) sophisticatedly managed by SMEs. But $29 \%$ of the SMEs are not successful in estimating their future cash flow.

\section{Hypothesis Testing}

The null hypothesis of the analysis was checked using a Chisquare test. The table indicates the parameters and scale of the freedom table and the $\mathrm{P}$-value corresponding with the chisquare value.

Table 4.1: A Chi-Square test of independent financial management practices versus the financial performance of SMEs in Chittoor District.

\begin{tabular}{|l|c|c|c|}
\hline & $\begin{array}{c}\text { Chi-Square } \\
\text { Value }\end{array}$ & df & $\begin{array}{c}\text { Asymp. Sig. } \\
\text { (2-sided) }\end{array}$ \\
\hline Financial reporting and analysis Vs. Financial Performance of SMEs in Chittoor District. & 9.566 & 2 & 0.008 \\
Fixed assets management Vs. Financial Performance of SMEs in Chittoor District. & 9.221 & 3 & 0.026 \\
Capital structure decisions Vs. Financial Performance of SMEs in Chittoor District & 10.999 & 3 & 0.012 \\
Working capital management Vs. Financial Performance of SMEs in Chittoor District. & 8.503 & 1 & 0.004 \\
\hline
\end{tabular}

The overall association between financial reporting analysis and the financial concert of the SMEs in Chittoor district was statistically significant $\left(\mathrm{X}^{2}=9.566, \mathrm{df}=2, \mathrm{p}=0.008\right)$.

The interrelation between fixed assets management and financial performance of SMEs in Chittoor district was statistically approved $\left(\mathrm{X}^{2}=9.221, \mathrm{df}=3, \mathrm{p}=0.026\right)$.

Capital structure decisions statistically noteworthy affiliation with the progress of financial performance of SMEs in Chittoor district $\left(\mathrm{X}^{2}=10.999, \mathrm{df}=3, \mathrm{p}=0.012\right)$.
There is a statistical substantial relationship between capital structure management and financial performance of SMEs in Chittoor district $\left(X^{2}=8.503, \mathrm{df}=1, \mathrm{p}=0.004\right)$.

\section{Correlation}

The Pearson product-moment coefficient of correlation was used to evaluate the relationship between the independent and the dependent variables.

Table 4.2: Pearson Correlation coefficients

\begin{tabular}{|c|c|c|c|c|c|}
\hline & 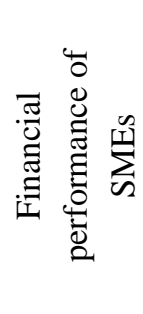 & 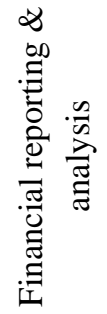 & 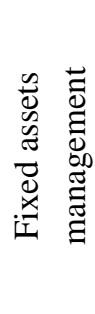 & 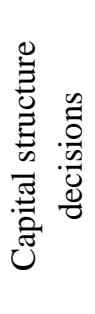 & 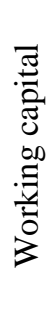 \\
\hline Financial performance of SMEs & 1 & & & & \\
\hline Financial reporting \& analysis & .093 & 1 & & & \\
\hline Fixed assets management & $.299^{*}$ & $.339^{* *}$ & 1 & & \\
\hline Capital structure decisions & $.262^{*}$ & $.321^{* *}$ & $.602^{* *}$ & 1 & \\
\hline Working capital management & $.347^{* *}$ & $.350^{* *}$ & $.350^{* *}$ & $.359^{* *}$ & 1 \\
\hline
\end{tabular}

*. Correlation is significant at the 0.05 level (2-tailed).

**. Correlation is significant at the 0.01 level (2-tailed).

Working capital management had the utmost constructive correlation coefficient with the financial performance of SMEs followed by fixed assets management and capital structure decisions. But financial reporting and analysis variable was a less positive correlation. 


\section{CONCLUSION AND RECOMMENDATION}

This present investigation's primary target was to analyse the effect of financial management practices on the financially related execution of SMEs in the Andhra Pradesh area of Chittoor. The data examination demonstrates that financial management rehearses majorly affect SMEs 'financial performance. Most of the organizations in the area of Chittoor set up their financial statements regularly and in accordance with guidelines. $98 \%$ of the SMEs are maintaining inventory records properly. This exploration shows that $94 \%$ of SMEs are maintaining cash balances to meet the daily requirements. The study illustrates that Capital structure may play a vital part in the financial performance of the SMEs.

The researcher recommends that SMEs recruit personnel with a critical assessment to conform to small and medium-sized enterprises' provisions. SMEs should also be motivated to distinguish their products and not go into their products from traditional practices.

Additionally, SMEs ought to be encouraged to fortify and set up arrangements with respect to account holders on the most proficient method to gather receivables, have the capacity to know when to discount awful obligations in order to limit misfortunes that accumulate because of none instalment. SME owners should also aim to ensure that stock governance is improved by setting rearrangement levels, both at a minimum and a more severe level, so that the company does not fall short of stocks and tie unnecessarily capital into stocks that affect working capital.

Fund and industrialization programs can provide a good stage for SMEs to obtain funding that will allow them to sustain their organizations at a high financial cost. It is important because access to bank advances for SMEs is troubling and uses the reserves generated. The funding costs should be high; comparably, the need to achieve such subsidies should also be responsive not to drive away SMEs.

\section{Limitation of the research study}

Financial and non - financial resources were real impediments in this study; time limitation and due to this limitation and scope of the study researchers have to limit the number of objectives. There are various areas of financial management straightforwardly or by implication identified with the research problem and research issue, however, all areas of financial management couldn't be explored because of the time limit and fund.

\section{Future research directions}

This study prompts the recommendation that in additionally inquire about work ought to supplement with the goal that different zones could be inspected which couldn't cover by this study. Following are the further recommendation for future research.

The current study has been conducted with 66 SMEs in Chittoor district only. This can be extended to another geographical region of Andhra Pradesh. The variables selected for the study limited to four, i.e. financial reporting
$\&$ analysis, fixed assets management, capital structure decisions, and working capital management. There are other variables which influence the financial performance of SMEs namely accounting information system, agency cost, budgeting system, costing system, and profitability management etc. This could be further developed and study by considering more variables. The consequence of the examination depends on the sample size of 66 , the results could be better if we take a large sample size from the universe.

\section{REFERENCES}

1. Abanis Turyahebwa et al. (2013). "Financial management practices and business performance of SMEs in western Uganda". African journal of business management, 7(38), 75-85.

2. Abudu Dawuda (2015). "An assessment of financial record keeping behaviour of small scale in business in Ghana: a case study of Bolgatanga municipality". International journal of finance and accounting, 4(3), 187-194.

3. Babar Zaheer butt et al. (2010). "Financial management practices and their impact on organizational performance". World applied sciences journal, 9(9), 97-102.

4. Dr Belal Yousef al smirat (2016). "Cash management practices and financial performance of SMEs in Jordan". Research Journal of finance and accounting, 2(20, 98-107.

5. Hande karadag (2015). "Financial management challenges in SMEs, a strategic management approach". Emerging markets journals, 5(1), 26-40.

6. Hendrik Wolmarans and Quentin (2015). "Financial management practices in successful SMEs". SAJESBM, 7, 88-116.

7. Irena Jindrichovska (2013). "Financial management in SMEs". European research studies, XVI, 80-95.

8. Kamilah Ahmad (2017). "The implementation of MAPs and its relationship with performance in SMEs". International review of management and marketing, 7(1), 342-353.

9. Kilonzo Jennifer M, Ouma Dennis (2015). "Financial management practices on growth of SMEs". IOSR journal of business and management, 17(8), 65-77.

10. Md. Asaduzzaman (2016). "Accounting and financial reporting practices of SMEs, Bangladesh perspective". Malaysian journal of business and economics, 3(1), 57-67.

11. Mohd Azian Husin, Mohamed Dahlan Ibrahim (2014). "The role of accounting services and impact on small medium enterprises performance in manufacturing sector from east coast region of Malaysia". Social and behavioral sciences, 115, 5467. 
12. Moujib Bahri Josee St.Pierre Ouafa Sakk (2017). "Performance measurement and management for manufacturing SMEs: a financial based system". Measuring business excellence, 21(1), 1-29.

13. M. W. Madurapperuma et al. (2016). "Accounting record keeping practices in SMEs in Srilanka". Journal of finance and accounting, 4(4), 188-193.

14. Padachi DK and Carole Howorth (2014). "Focus on working capital management practices among Mauritian SMEs: survey evidence and empirical analysis". E3 Journal of management and economics, 5(4), 97-108.

15. P. S. Vohra and J. S. Dhillon (2014). "Best financial practices lead financial performance of SMEs". International journal of accounting and financial management research, 4 (3), 5-16.

16. Rajiv Narayanapillai (2014). "Inventory management practices in small and medium machine tool enterprises in India: what differentiate between enterprises?" Asian journal management sciences, 02 (04), 01-07.

17. Saqib Muneer et al. (2017). "Impact of financial management practices on SMEs profitability with moderating role of agency cost". Information management and business review, 9(1), 23-30.

18. Suparak Suriyankietkaew and Gayle Avery (2016). "Sustainable leadership practices driving financial performance: empirical evidence from Thai SMEs, Sustainability, 8, 1-14.

19. Tim Mazzarol et al. (2015). "Financial management practices in SMEs". $28^{\text {th }}$ annual SEAANZ conference proceedings, 1-22.

20. U. A. H. A. Rathna Siri (2015). "The Financial Management practices of SMEs in Srilanka". Global journal of contemporary research in accounting, auditing \& business ethics, 1(2), 374-399. 